\title{
Congratulation to the Issue of Vitamins \& Trace Elements
}

\section{Jianbo Qu*}

Center for Bioengineering and Biotechnology, China University of Petroleum (East China), P.R. China

With the rapid development of biotechnology, bioseparation become more and more important owing to the high requirement of human healthcare to the purity of bioproducts. Considering this point, the overspread of bioseparation knowledge is necessary and useful. For example, in my research area, liquid chromatography (LC) is an important tool and a necessary step for the separation and purification of biological macromolecules owing to its high resolution and mild separation conditions. However, most researchers only limited to use the conventional method and matrix in their daily work. The open access of journal to the scientist especially for the technologist is therefore very necessary.
Vitamins \& Trace elements, just as the name implies, have very little content in the human body. However, they play important role in the health of human body. Incorporated with amino acid, protein, vitamin or other organic groups in the body, they have high biological activity and catalytic activity. Many important substances of life in the body can not work if in short of trace elements, especially the participation of metal elements.

In summary, I do think the open access Journal of Vitamins \& Trace elements is significant to the human health all over the world. I would like to contribute my scientific enthusiasm and experience to the journal.
*Corresponding author: Jianbo Qu, Assistant Professor, Center for Bioengineering and Biotechnology, China University of Petroleum (East China), P.R. China, Tel: 0086-532-86981566; Fax: 0086-532-86981566; E-mail: jbqu@upc.edu.cn

Received January 09, 2012; Accepted January 09, 2012; Published January 11 2012

Citation: Qu J (2011) Congratulation to the Issue of Vitamins \& Trace Elements. Vitam Trace Elem 1:e101.

Copyright: (c) $2011 \mathrm{Qu} \mathrm{J}$. This is an open-access article distributed under the terms of the Creative Commons Attribution License, which permits unrestricted use, distribution, and reproduction in any medium, provided the original author and source are credited. 